\title{
Analysis of Glocalization Phenomena: Advertising of Starbucks Special Edition Products with Indonesian Local Wisdom in Social Media
}

\author{
$1^{\text {st }}$ Ananda Dwitha Yuniar \\ Universitas Negeri Malang \\ Indonesia \\ ananda.dwitha.fis@um.ac.id \\ $2^{\text {nd }}$ Ahmad Fikri Ainurrizqi \\ Universitas Negeri Malang \\ Indonesia
}

\author{
$3^{\text {rd }}$ Amelia Firda Tresnayanti \\ Universitas Negeri Malang \\ Indonesia
}

\author{
$4^{\text {th }}$ Amelia Firda Rahma \\ Universitas Negeri Malang \\ Indonesia
}

\author{
$7^{\text {th }}$ Alan Sigit Fibrianto \\ Universitas Negeri Malang \\ Malang, Indonesia \\ alan.sigit.fis@um.ac.id
}

\author{
$5^{\text {th }}$ Rizki Amalia \\ Universitas Negeri Malang \\ Indonesia \\ $6^{\text {th }}$ Siti N. Zulaikha \\ Universitas Negeri Malang \\ Indonesia
}

\begin{abstract}
Globalization has had an impact on the creation of a national economic climate that also impacts on the local economy. The era of decentralization that demands regional independence has encouraged the birth of local potentials that are able to take advantage of the opportunities of globalization to show their local tastes inforeign countries. This study is aimed at analyzing the phenomenon of glocalization in global products which launches a blend of local culture in advertising on social media. This study uses descriptive methods, namely methods that discussseveral possibilities for solving actual problems by collecting data, compiling or classifying, analyzing, and interpreting it. The results of this study indicate that glocalization creates heterogeneity by elevating local culture in the global world. The role of technologicals ophistication and the use of social media helps the process of appointing local culture into the global world.
\end{abstract}

Keywords: globalization, glocalization, local wisdom, social media

\section{INTRODUCTION}

Globalization is a word that has not been discussed and is not something that has only been known by the public in several countries. All discourses on globalization are rolling long accompanied by diverse perspectives to give meaning to 'globalization'. The increasingly sophisticated and rapid advances in technology and information are pushing the boundaries between countries to almost disappear. In other words, globalization presents a closer distance between countries to establish cooperative relations. All countries, whether forced or not, are racing to stay on the path of globalization. Globalization that is familiar and familiar with the meaning of capitalism, liberalism and creating uniformity in many things including culture, is not always able to be taken for granted.

Lessons from the implications of globalization in the 19th and 21 st centuries which led to rampant inequality and poverty led to the anti-globalization movement commonly known as the localization phenomenon. Through this localization phenomenon, it is hoped that a change in mindset will occur as a breakthrough for the existence of indigenous cultures but can become an opportunity for local existence. Glocalization as globalization with local flavor is a concept that must be managed properly. It cannot be denied that globalization has driven convergence in economic policy, culture between countries. Local existence should be able to provide answers with the presence of glocalization.

Phenomena make globalization an opportunity for the existence of culture and local products not only to be regional and to be traded in regions but globally. Local products 


\section{LITERATURE REVIEW}

belonging to regions that have distinctive features are likely to be able to compete in foreign markets. This phenomenon has happened a lot in Indonesia, except that regulations are needed to support some of these local products to compete in the international arena. In other words, Indonesia must have the courage to compete in the midst of globalization, not just to survive in the downturn. All communities and their governments both at the local and central levels must jointly have the confidence that Indonesian products are able to hold control in the game of globalization. Culinary and other types of wealth become one of the many characteristics of the Indonesian nation so that there are many opportunities to create profitable innovations in the field of the economy in particular, and in other fields.

One of the local potentials of the Indonesian nation is culinary delights, snacks, bread and so on. With the impact of globalization, one of which is favored by teenagers and many people is a cafe to hang out has issued food products whose ingredients show a distinctive Indonesian taste collaborated with modern nuances so that it is more popular with visitors. This paper intends to see the potential in terms of local cuisine as a form of the phenomenon of glocalization.

As a comparison from previous research, in 1983 Theodore Levitt published the article "The Globalization of Markets" [1], which contained opinions on the global market for the equality of services and products. Levitt argues that multinational companies set standards for services and products produced internationally with principles of reliability, functionality, and low prices. Next is the journal "The Existence of Local Potential in the Glocalization Phenomenon: Learning from Krebet Wood Batik" Krebet tourism village from Sendangsari Village, Yogyakarta which sells a variety of unique, beautiful and elegant wooden batik handicraft items. Compiled by [2] Which focuses on developing the local potential that is seen that there are still opportunities for the local potential to show their existence at the international level. Next, in 2012 there is a phenomenon that makes the world of music glance at South Korea, an article titled "GangnamStyle and Glocalization Phenomenon" worldwide popularity thanks to the internet media, the Youtube platform that brought Gangnam style to a boom [3]. Next in the realm of the music world too, industrialization in the Bali Province felt a sense of loss. One of the factors is the practice of Balinese pop music glocalization in Bali. (Factors Causing Bali Pop Music Glocalization Practices) [4]. The difference between this research is focusing on the analysis of the role of advertising in social media regarding the product of vocalization made by one of Starbucks global brands. The researcher focused on reviewing official Instagram social media owned by Starbucks Indonesia.

\section{A. Globalization}

Indonesia is a diverse country with various ethnic groups, races, and cultures. If talking about globalization in the scope of Indonesia, then there will be no end to the word 'globalization' to be discussed. Because there are various kinds of perspectives that will assess the meaning or meaning of globalization itself according to the perspective of each society in Indonesia. Apart from various perspectives on the meaning of globalization, according to Winanti [2] explained that globalization can be interpreted as a historical process that arises from the development of advances in communication and information technology. With the existence of globalization, it creates ease between countries in collaborating. Not only between countries but also intra-state. With the advancements in technology, people can easily do work or communicate with other parties even at great distances. In this case, it can be understood that globalization is a process of increasing relations between people in one country and between countries with other countries. Technology as a product of globalization also participates in mastering every human behavior throughout the world, so that it can change the behavior patterns of people wherever they are [5]. On the other hand, technology also has a good impact on the formation of images for certain groups of people, including minorities [6]. Technology also plays a role in the formation of image and prestige [7].

\section{B. Local Wisdom}

As a multicultural country, Indonesia certainly has a variety of cultures and local wisdom in it. However, over time and the influx of globalization into Indonesia, not a few Indonesian cultures are lost and replaced by foreign cultures. If this continues, Indonesia will lose its identity as a multicultural country. Talking about culture is inseparable from the name of local wisdom. Local wisdom itself is a part of a culture so that when Indonesian culture is eroded by the flow of globalization, it does not rule out the local wisdom in the culture which has also been eroded by globalization.

According to Haryati Subadio [8] explained that local wisdom is a cultural identity or cultural personality of a nation. Meanwhile, the concept of local wisdom put forward by Quaritch Wales [8] is all the cultural traits of a country that come from the results of past experiences or "... the result of their experience in early life ". Based on these two thoughts, it can be concluded that local wisdom is a characteristic of culture or cultural identity of a nation or country derived from the results of past community experiences.

\section{Glocalization}

Culture and local wisdom is a legacy that must be preserved by future generations. However, seeing the reality at this time 


\section{RESULTS AND DisCUSSION}

many local cultures and local wisdom has been eroded by the flow of globalization. This will have an impact on the loss of Indonesia's national identity as a multicultural country. The rapid flow of globalization into Indonesia has created many new cultures that are not in accordance with the culture in Indonesia. New cultures that arise due to the current of globalization can be said to be a culture of glocalization.

Glocalization arises when local culture is unable to survive under the pressure of globalization, creating glocalization. According to Eko Budiharjo [2], glocalization is globalization with a unified local cultural element or "globalization with local flavor". Whereas according to Wordspy [9] glocalization is a product creation aimed at global markets but adapted to local culture. Based on these two things, it can be concluded that glocalization is a creation of a new culture with global elements that are united with local elements, where the new culture or product adapts to the characteristics of the global target community.

\section{METHOD}

The method used in this research is descriptive research method, which is a method that discusses several possibilities for solving actual problems by collecting data, compiling or classifying, analyzing, and interpreting it. This study focuses on the analysis of the role of advertising in social media regarding the product of vocalization made by one of Starbucks' global brands. The researcher focused on reviewing official Instagram social media owned by Starbucks Indonesia. The analysis was carried out by reviewing uploads from the official Starbucks Indonesia Instagram account of the glocalization products made. Next, the researcher interpreted the description that appeared in the upload and categorized it into the process of glocalization, so that results could be achieved in the form of the role of social media advertising in the process of glocalization.

Globalization according to Baylis \& Smith (in Hartanto, 2018 ) is a process of increasing linkages between communities throughout the world so that events that occur in a part of the world increasingly affect communities in other parts of the world. whereas according to Held et al [9] globalization is a series of processes that embody transformation of the spatial organization of social relations and transactions. Based on the two definitions according to the two figures, it can be concluded that globalization is a process of increasing linkages between communities throughout the world that realize transformation so that it has a significant impact on the blowing of society in a country.

\section{A. Glocalization Phenomenon in Starbucks Special Edition Indonesian Products}

The phenomenon of globalization that has mushroomed in various parts of the world including Indonesia can no longer be prevented or hampered by the entry process. Increasingly, with globalization, the local cultures in Indonesia are increasingly eroded and eventually replaced by western culture. Local cultures that are threatened by sustainability are not only in terms of ancestral values but also in terms of the social life of the community. The result that will be caused by the mushrooming of globalization in Indonesia is that Indonesia will forget its identity. Where Indonesia is a multicultural country that is rich in natural resources, ethnicity, race, religion, and culture.

Globalization and modernization are two interrelated things where globalization brings the current of modernization. Globalization that is happening in Indonesia at the moment influences Indonesian traditional culture, one of which is the lifestyle of drinking coffee or commonly called Ngopi. The culture or lifestyle of drinking coffee in the past was only limited to fulfilling the desire to drink coffee or to just "chat with friends" when visiting. But it is different from the culture or lifestyle of Ngopi at the moment. The culture of drinking coffee at this time is not just a desire for fulfillment of desire but has spread into the realm of the current lifestyle. The lifestyle referred to here is that Ngopi is not only limited to fulfilling desires but also reflects social class. The more classy Ngopi places visited, the more classy the lifestyle of a person and the more classy the place is, the more expensive the price of coffee offered.

Speaking of classy Ngopi places or commonly called Coffee Shop, there is one place that is famous not only abroad but also in Indonesia, Starbucks. Starbucks Corporation is an American coffee company based in Seattle, Washington. Starbucks is a coffee shop company that is very popular in the world and has opened around 15,012 stores in 44 countries around the world. This Starbucks logo comes from Siren, which is a double-tailed mermaid, or what is called the Siren name which is very popular in stories in Greek mythology. In addition, this logo has the meaning "spirit of Seattle" because in the 70s Seattle was a Seattle city famous for its fame.

Starbuck first appeared in Indonesia because PT Mitra Adhi Perkasa obtained a license to operate Starbucks in Indonesia. Furthermore, PT Mitra Adhi Perkasa appointed Anthony Cotton, who is experienced in Customers Service, to launch and manage the brand. Anthony with 8 members from Jakarta wanted to study for 3 months in Seattle, before opening the first store in May 2002. Until now Starbucks had branches in various countries including Indonesia. In Indonesia alone, Starbucks is spread in various big cities such as Jakarta, 
also considered to be broader because it not only covers the domestic area but also can reach the global market.

Nowadays the sophistication of technology and the phenomenon of globalization are pushing the whole world to become one without limitations. Globalization is often seen as a homogeneity. The term homogeneous itself is created because of the mixture of various cultures because of the loss of boundaries in the global world. The statement on the theory was later refuted by [10] who views the other side of globalization as causing heterogeneity because of a mixture of cultures which brings one of the local identities to further reach the global world or be called glocalization [12]. This is indicated by the presence of product innovations to elevate their local culture to the global world, by integrating local culture with global culture. In addition to elevating local culture, the glocalization products are also intended to reach local markets that tend to be traditional or difficult to accept global products.

These product innovations were then developed through advertising media to reach a wider market both locally and globally. Advertising of these glocalization products plays an important role in the process of glocalization, where local products can be raised in the global world. One of the most appropriate media for advertising these glocalization products is social media. An example of the globalization product advertisements is Starbucks Pandan Gula Aren, which is one of Starbucks cake innovation. This product is advertised through the Starbucks Indonesia official social media account.

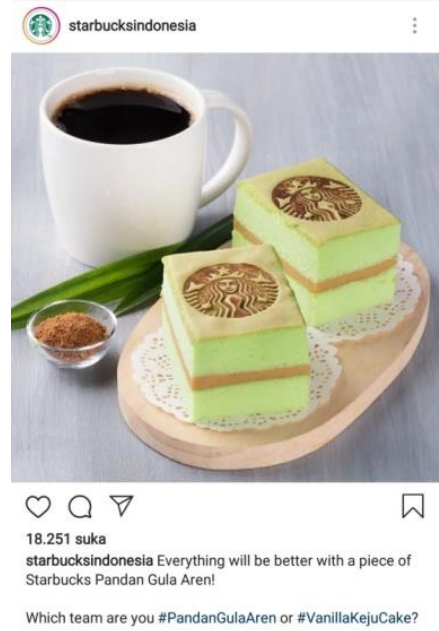

Fig. 1. Advertisement of Starbucks Glocalization Product

From these advertisements, it can be analyzed that Starbucks as a global brand seeks to penetrate the local market by displaying innovative products that combine global cuisine (cake) with local flavors (palm sugar pandanus). on the ad, there are also two hashtags that align the glocalization products 
(palm sugar pandanus) with global products (vanilla cheesecake). This can have an impact on broader product introduction, if Instagram users do a search with hashtag \#VanillaKejuCake then this ad will appear in the search so users from all over the world can get to know palm sugar cake pandanus from Starbucks.

Starbucks itself originally developed in America, the first store was established in 1971 [13]. At first, Starbucks only developed in North America, until in 1996 Starbucks opened the first store outside of America, precisely in Japan and Singapore. Starbucks coffee shop brands develop various aspects of their business such as obtaining various licenses, establishing international cooperation, and developing coffee farms to ensure product quality. This coffee shop brand began entering the Indonesian market in 2002, the first store opened at Plaza Indonesia Jakarta and continued opening at the second store located in Tunjungan Plaza Surabaya. Starbucks has a concept to bring the taste of coffee stew from various regions with a distinctive taste of Starbucks, both original and blend products.

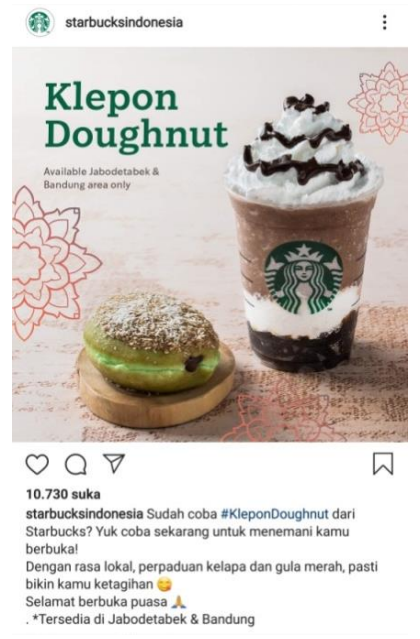

Fig. 2. Starbucks Glocalization Product

This following table is the analysis of the Advertisement on Starbucks official social media account between global products and glocalization products.

TABLE I. TABLE Styles

\begin{tabular}{|c|c|c|}
\hline$\overline{\text { Aspect }}$ & $\begin{array}{l}\text { Starbucks's Global } \\
\text { Product (Original) }\end{array}$ & $\begin{array}{c}\text { Starbucks's } \\
\text { Glocalization Product }\end{array}$ \\
\hline Launching & $\begin{array}{l}\text { Every turn of the season } \\
\text { raises new products, } \\
\text { advertising accompanied by } \\
\text { the availability of limited } \\
\text { edition products, posting } \\
\text { new product innovations. }\end{array}$ & $\begin{array}{l}\text { Each particular event in } \\
\text { the destination country } \\
\text { (ex: Ramadhan in } \\
\text { Indonesia), advertising } \\
\text { products of cooperation } \\
\text { with Indonesian artists. }\end{array}$ \\
\hline Product & Products in the form of & Products in the form of \\
\hline
\end{tabular}

\begin{tabular}{|c|c|c|}
\hline Aspect & $\begin{array}{l}\text { Starbucks's Global } \\
\text { Product (Original) }\end{array}$ & $\begin{array}{c}\text { Starbucks's } \\
\text { Glocalization Product }\end{array}$ \\
\hline Modification & $\begin{array}{l}\text { coffee innovations, blends, } \\
\text { and cakes that are adapted to } \\
\text { the season (ex: summer, } \\
\text { identical to products with a } \\
\text { mixture of tropical fruits), } \\
\text { member cards and } \\
\text { merchandise that be adapted } \\
\text { to the season. }\end{array}$ & $\begin{array}{l}\text { global product cake } \\
\text { innovations combined } \\
\text { with Indonesian flavors } \\
\text { (ex: klepon doughnut, } \\
\text { pandan cheesecake), } \\
\text { member card and fan } \\
\text { merchandise that be } \\
\text { adapted to events in } \\
\text { Indonesia (ex: } \\
\text { independence day, } \\
\text { Ramadhan), tumbler and } \\
\text { bearista doll products } \\
\text { modified by } \\
\text { collaborating with local } \\
\text { artists. }\end{array}$ \\
\hline Availability & $\begin{array}{l}\text { Available at all Starbucks } \\
\text { stores during the specified } \\
\text { period }\end{array}$ & $\begin{array}{l}\text { Some products such as } \\
\text { merchandise are } \\
\text { available at Starbucks } \\
\text { stores throughout } \\
\text { Indonesia, some limited } \\
\text { edition products are } \\
\text { available in selected } \\
\text { regions or Starbucks. }\end{array}$ \\
\hline $\begin{array}{l}\text { Design of } \\
\text { Advertisement }\end{array}$ & $\begin{array}{l}\text { Advertisement is } \\
\text { accompanied by product } \\
\text { descriptions by including the } \\
\text { main ingredients of the } \\
\text { product. }\end{array}$ & $\begin{array}{l}\text { Photos of food products } \\
\text { are accompanied by } \\
\text { global Starbucks } \\
\text { products and hashtag of } \\
\text { Starbucks global } \\
\text { products, merchandise } \\
\text { products are } \\
\text { accompanied by special } \\
\text { promos. }\end{array}$ \\
\hline $\begin{array}{l}\text { Intensity of } \\
\text { Advertisement }\end{array}$ & $\begin{array}{l}\text { Advertisement is uploaded } \\
\text { with high intensity on each } \\
\text { Starbucks social media of } \\
\text { each country. }\end{array}$ & $\begin{array}{l}\text { Advertisement is } \\
\text { uploaded with the low } \\
\text { intensity and only posted } \\
\text { on Starbucks Indonesia } \\
\text { social media accounts. }\end{array}$ \\
\hline
\end{tabular}

From the exposure of the data above, it can be analyzed that the core of the differences in global products and glocalization product lies in product modification. Global products are original products from a global brand with its own brand characteristics, global products themselves tend to be modified by following consumer interests such as presenting products according to the current season or modifying products with various trendy materials. Glocalization products are made by a global brand by modifying the original products that already existed with a touch of local flavor, the glocalization product is not a completely new product but rather a combination of original products with various local cultures that already exist. In this context Starbucks global brand seeks to bring global into the local world, where the product of glocalization created by Starbucks is a global product that has been modified with local flavors to suit the interests of local consumers.

According to Robertson, in the world of business, glocalization itself is seen as an economic rule by taking into account the intended regional context. This includes the 
production and advertising of products also services that have been adapted to the local context. Where various strategies have an important role in the process of glocalization, Starbucks itself has a strategy in product launching, product availability, advertising, and managing intensity of product advertising.

If the core of globalization is the impact of modernization, where the whole world follows a new trend with western countries as its qibla, then the core of glocalization is deconstruction of modernization itself where countries that are westernized respond to the entry of various western new cultures by modifying them with culture local. By bringing up the product of glocalization, Starbucks indirectly brought modern culture into the local. This phenomenon can also be an ambiguity where the global brand that brings modernity deconstructs modernity created by the emergence of glocalization products.

These various strategies are intended to control glocalization, which refers to the balance in the process between globalization and glocalization. The essence of globalization and glocalization itself is a matter of homogeneity and heterogeneity. In glocalization, this matter is not a comparison to be debated. Homogeneity and heterogeneity are systems that affect each other, where the creation of homogeneity from the emergence of global products will be responded to again by local cultures, resulting in increasingly diverse heterogeneity. Starbucks strategy in an effort to control homogeneity and heterogeneity itself is done by making glocalization products with limited availability, the variety of products that are raised as well as product promotions are also limited by utilizing major events in Indonesia. In this case, Starbucks strives to suppress the heterogeneity that arises from the product of the glocalization made. It also functions as control over the clear boundaries between global products and local products so as to minimize the impact of the cultural shock that will occur due to the fading of local culture.

A brand's social media account also plays a role in the process of glocalization. A global brand like Starbucks certainly has branches all over the world, making social media accounts in every country needed to facilitate their customers. Indirectly this has created glocalization where the loss of global boundaries will create increasingly complex heterogeneity. Each branch in every country in the world certainly has a glocalization product because generally, a brand such as Starbucks has the same system throughout the world.

\section{CONCLUSION}

Glocalization is a concept about a world that began to change from homogeneous due to the proliferation of modernization and also westernization to be heterogeneous as a response to modernization itself. This is done by the process of combining global (modern) culture with the local culture so that the local culture also has an existence in the global world. Global Starbucks brand also brings the phenomenon of glocalization to Indonesia by combining its global products with a variety of Indonesian local wisdom. With this phenomenon Starbucks has reached 4 important elements in the process of glocalization which is presenting a more pluralistic world, encouraging individuals or groups to adapt, innovate, and maneuver in a world experiencing glocalization, creating social processes that are interconnected and depend on one with the others, and commodities and media are not viewed as (fully) coercive, but rather provide material for use in the creation of individuals or groups throughout the world who experience glocalization.

Starbucks has various strategies in advertising and manufacturing glocalization products where the strategy is intended to control the created glocalization. Starbucks strategy in an effort to control homogeneity and heterogeneity itself is done by making glocalization products with limited availability, the variety of products that are raised as well as product promotions are also limited by utilizing major events in Indonesia. In this case, Starbucks strives to suppress the heterogeneity that arises from the product of the glocalization made. It also functions as control over the clear boundaries between global products and local products so as to minimize the impact of the cultural shock that will occur due to the fading of local culture.

\section{REFERENCES}

[1] Sayogi, Yekti Sakanti 2013 Analisis Glokalisasi Perusahaan Multinasional Sebagai Bentuk Strategi Komunikasi Kaum Bridgehead (Studi Kasus McDonald's dan Mahasiswa Universitas Indonesia) (Depok: Fakultas Ilmu Sosial dan Ilmu Politik Universitas Indonesia).

[2] Marlina, Neny 2015 Eksistensi Potensi Lokal dalam Fenomena Glokalisasi: Belajar dari Batik Kayu Krebet Government: Jurnal Ilmu Pemerintahan JIP08(2015)002.

[3] Nugroho, Wahyu Budi 2012 Gangnam Style dan Fenomena "Glokalisasi" on (http://kolomsosiologi.blogspot.com /2012/10/gangnam-style-dan-fenomena-glokalisasi-html?m=1).

[4] Ardini, Ni Wayan 2016 Faktor-Faktor Penyebab Praktik Glokalisasi Musik Pop Bali Jurnal Seni Pertunjukan JSP02(2016)002.

[5] Fibrianto, A. S., \& Yuniar, A. D. (2019, June). Technological Development and its Impact on Community Social Behavior. In 1st International Conference on Social Knowledge Sciences and Education (ICSKSE 2018). Atlantis Press.

[6] Fibrianto, A. S., \& Yuniar, A. D. (2019, August). The Representation of Diffable Community's Creative Service Industry in Yogyakarta Indonesia. In First International Conference on Administration Science (ICAS 2019). Atlantis Press.

[7] FIBRIANTO, A. S. (2018). Praktik Sosial Komunitas Difabel 'Difa City Tour dan Transport'dalam Proses Hubungan Industrial (Studi Kasus pada Perusahaan Industri Jasa Kreatif Ojek Online Kalangan Difabilitas Berbasis Komunitas di Yogyakarta) (Doctoral dissertation, Universitas Sebelas Maret). 
[8] Brata, Ida Bagus. 2016. Kearifan Budaya Lokal Perekat Identitas Bangsa. Jurnal Bakti Saraswati JBS05(2016)001.

[9] Hartanto 2018 Startegi Perusahaan Multinasional di era Globalisasi 9 (Studi Kasus Glokalisasi dalam Ekspansi "Indomie" ke pasar Timur Tengah dan Afrika) Jurnal Sosial dan Humaniora JSH03(2018)005.

[10] Robertson, Roland 1992. The Globalization Paradigm: Thinking Globally (Greenwhich: JAI Press).
[11] Pertiwi, W.K. 2019 Riset Ungkap Pola Pemakaian Medsos Orang Indonesia On www.kompas.co.id

[12] Featherstone. M, Lash. S, Robertson. R. 1995 Global Modernities (London: Sage Publication).

[13] Starbucks Coffe Company. 2011. Starbucks Company Timeline on www.starbucks.co.id 